\title{
Qualitative Analysis of Innermodel Indirect Effects Consumption Patterns of Jambi City Society in Ramadan
}

\author{
$1^{\text {st }}$ Habriyanto \\ \{habriyanto@uinjambi.ac.id ${ }^{1}$ \} \\ UIN Sulthan Thaha Saifuddin Jambi ${ }^{1}$
}

\begin{abstract}
The Model Indirect Effects of Community consumption patterns uses a quantitative research approach where the data collection tool uses a questionnaire with 140 samples of respondents. The results showed that the religiosity factor indirectly influenced the consumption pattern of the Jambi city community through social factors. Fasting worship in the month of Ramadan as a religious order gives birth to social interaction to create a culture and tradition such as in fulfilling the food menu in breaking the fast, buying new food and clothes to welcome Eid al-Fitr, and the tradition of gathering and going home.
\end{abstract}

Keywords: Religious Factors, Social Factors, Consumption Patterns, Indirect Effects.

\section{Introduction}

One of the activities carried out by humans is consuming. Consumption is part of the fulfillment of physical needs which include the fulfillment of basic needs (primary), complementary needs (secondary), and luxury needs (tertiary). In the activity of fulfilling consumption needs, each individual has a different character from one another. So that these differences form a pattern in the consumption activities of a product. The pattern of consumption that is formed is largely determined by several influences or some variables that influence it. One of the variables that influence the formation of consumption patterns is religiosity and social factors. A study showed that seniority in the profession and religiosity have a positive influence on ethical awareness. In the theoretical approach, deontology has a positive influence on ethical consciousness, while egoism has a negative influence [1]. This means that practicing religious teachings in daily life will have an effect and ethical awareness in social life. An understanding of the influence of religiosity on consumption patterns can be explained in the following verse:

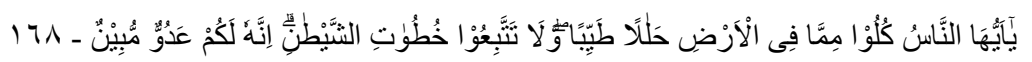

This means,

all humans, eat what is lawful and good from what is on earth, and do not follow the steps of the devil; for verily the devil is a real enemy to you. (Al-Baqarah, 2:168).

Based on the verse above, it can be understood that the command of religiosity through the Qur'an forms a consumption pattern, namely the goods to be consumed must have a clear level 
of halal and goodness and do not cause harm to consumer health. The same thing is also stated in a study that consumer behavior in the market is influenced by five variables, namely commitment, motivation, affiliation, knowledge of religion, and awareness of the social consequences of following a religion [2].

The influence of religiosity factors that indirectly affect consumption patterns through social factors. Phenomena that can be seen through community activities in Jambi cities in the month of Ramadan where when compared to other months, in the month of Ramadan, consumption is seen to increase. Busy market conditions, the number of traders increased by offering several products for needs during the month of Ramadan. And the need for Eid. The increase in the number of home comers for Eid in their hometown also increases consumption expenditure.

The phenomenon that occurs is certainly not following the concept of fasting where fasting provides a lesson for Muslims to live simply and avoid excessive consumption activities. The conditions that occur are interesting to study more deeply and find solutions so that the sacredness and wisdom of fasting in the month of Ramadan are maintained properly.

\section{Literature Review}

\section{Definition of Religiosity}

Religiosity comes from the word religion (religion). The meaning of religion comes from the Arabic al-din, which means law or law. This word contains the meaning of mastering, subjugating, obeying, debt, recompense, habit while religion (Latin) or relegate means collecting and reading [3]. According to Majid religiosity is human behavior that is entirely shaped by the belief in magic or the supernatural, namely supra-empirical realities. Humans perform empirical actions as appropriate, but humans who have religiosity put the value and meaning of their empirical actions under the supra-empirical [4]. According to Spranger religiosity is the belief in which people feel and acknowledge the supreme power, which houses the life, and to Him dependent and surrender. According to RH Thouless in Darajat, religion is a process of the perceived human relationship to something he believes, that something is higher than humans [5]. Barnett et al stated that religiosity is usually defined in terms of (1) cognitive, ie religious knowledge and religious beliefs; (2) affective, namely emotional closeness or emotional feelings about religion; (3) behavior, namely the behavior of individuals related to religion, for example visiting places of worship, reading scriptures, and praying [6].

Based on the explanation of some of the definitions above, it can be concluded that religiosity is all human behavior based on belief in God by trying to carry out all the rules and norms in life based on the teachings of God.

\section{Definition of Social}

Social is an activity related to society [7]. Whereas the notion of social interaction is a relationship between people who produce a permanent relationship that allows the formation of the social structure. The outcome of the interaction is largely determined by the values and meanings and interpretations given by the parties involved in this interaction [8]. 


\section{Definition of Consumption Patterns Consumption}

Patterns are the way consumers carry out consumption activities (ie in utilizing goods or services) based on various conditions (income, age, lifestyle, education, occupation, and others). Thus, the character, needs, desires, abilities, and tastes are not the same from one person to another. This condition causes the consumption pattern of each person to be different.

\section{Relation of Religious Factors with Social Factors}

A study showing that religiosity influences social life, is supported by a study using 690 respondents in Malaysia which shows that religious awareness influences compliance in paying zakat which is one form of social worship [9].

Religion can't be separated from social life, because religion itself is necessary for social life. According to Jalaluddin in practice the function of religion in social life, among others [3]. a. Functional Educational

Religious adherents believe that the teachings of the religion they profess provide teachings that must be obeyed. Legally, religious teachings have the function of ordering and forbidding. The two elements of command and prohibition have a directing and guiding background so that the adherents become good and get used to what is good according to the teachings of their respective religions.

b. Functioning savior

Wherever humans are he always wants himself to be safe. The salvation which covers a wide field is the salvation taught by religion. The salvation given by religion to its adherents includes the salvation of the world and the hereafter. In achieving salvation, religion teaches its adherents through an introduction to sacred issues, in the form of faith in God.

c. Functioning as peace

Through religion, a person who is guilty or sinful can achieve inner peace through religious guidance. The guilt and guilt will soon become lost from his heart when a person who violates has atoned for his sins through repentance, purification, or penance.

d. Functioning as social control

The adherents of religion following the teachings of the religion they embrace are mentally bound to the demands of these teachings, both individually and in groups. Religious teachings in this case function as social supervisors individually or in groups because religion as an institution is the norm for its followers, and religion dogmatically (teaching) has a critical function that is prophetic (revelation, prophethood).

e. Functioning as a cultivator of a sense of solidarity

The followers of the same religion psychologically will feel they have something in common in one unit. Faith and trust. This sense of unity will foster a sense of solidarity within groups and individuals, sometimes even fostering a strong sense of brotherhood. In some religions, the sense of brotherhood can even overpower the sense of nationality.

f. Functioning transformative

Religious teachings can change the life of a person's personality or group into a new life following the teachings of the religion he adheres to. The new life he received based on the teachings of the religion he embraced was sometimes able to change his loyalty to the customs or norms of life that he had previously embraced.

g. Creative Functions

Religious teachings encourage and invite adherents to work productively not only for their interests but also for the interests of others. Adherents of religion are not only told to work 
regularly in the same lifestyle, but are also required to innovate and make discoveries.

h. Functioning Sublimation

Religious teachings sanctify all human endeavors, not only those of a hereafter religion but also those of a worldly nature. All human efforts do not conflict with religious norms if done on a sincere intention, as and to God is worship

\section{Religiosity Factor Relationship with Consumption Pattern In the month of Ramadan}

The Islamic Sharia has a set of ethics and norms in consumption based on the Al Islami Quran and As-Sunnah. Some of these ethics have a role and influence in the formation of Islamic consumption patterns, consumption patterns taught in Islamic religiosity include justice, cleanliness, simplicity, halalan tayyibah, and balance [10]. According to Yusuf Qaradawi, there are three grounding Norma consumption patterns, namely: Simple in consuming a product, not wasteful, and spending treasure for the good. According to Naqvi, Islamic ethics that can influence consumption patterns are grouped into four main axioms, namely: monotheism, justice, freedom of will, and responsibility. With the following exposure: [11].

Meanwhile, according to Kahf consumption targets for Muslim consumers are as follows: 1) Consumption for self and family, 2) Savings, and 3) Consumption as a social responsibility [12], [11]. According to MA Mannan, five basic principles control consumption pattern activities following Islamic ethics, namely: 1) The principle of justice, 2) The principle of cleanliness, 3) The principle of simplicity, 4) The principle of generosity 5) The principle of mortality [13].

\section{Methodology}

Methods This research method uses a quantitative research approach using SEM-PLs indirect effects and data collection using a questionnaire method using 140 samples.

\section{Result and Discussion}

The test results of the path coefficients between latent variables produce the following description: 


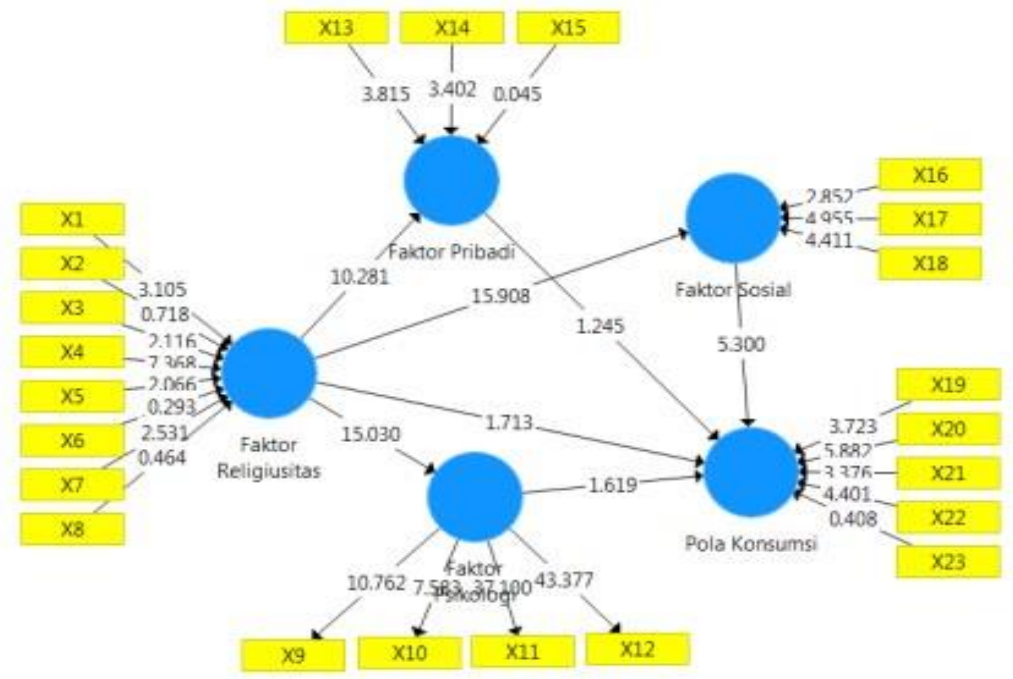

Fig. 1. Test results of the path coefficients between latent.

Figure 1 above can be seen that the indirect influence of religiosity factors consisting of formative variables of monotheism (X1), cleanliness (X3), simplicity (X4), trustworthiness (X5 ), and generosity (X6) through intervening variables, social factors, reference group format variables (X16), social class (X17) and culture (X18) towards the pattern consumption of the Jambi city community in the month of Ramadan consisting of the price of goods (X19), income (X20), tastes and habits (X21) and the number of family members (X22).

\subsection{Model Indirect Effects}

Model Indirect Effects portrait of the relationship and the influence of exogenous variables and intervening variables that are indirectly related or affect the endogenous variables. The indirect relationship and influence on endogenous variables is a form of link in a structural model. The following table will present the results of the test Indirect Effects and the form of the relationship or influence between exogenous variables, intervening variables, and endogenous variables. 
Table 1. Indirect Effects.

\begin{tabular}{|c|c|c|c|c|c|}
\hline & $\begin{array}{c}\text { Origina } \\
\text { l } \\
\text { Sample } \\
(\mathrm{O})\end{array}$ & $\begin{array}{c}\text { Sampl } \\
\mathrm{e} \\
\text { mean } \\
(\mathrm{M})\end{array}$ & $\begin{array}{c}\text { Standard } \\
\text { Deviation } \\
(\mathrm{STDEV})\end{array}$ & $\begin{array}{c}\text { T Statistics } \\
(|\mathrm{O} / \mathrm{STDEV}| \\
)\end{array}$ & P Values \\
\hline $\begin{array}{c}\text { Latent variable } \\
\text { factors religiosity -> } \\
\begin{array}{c}\text { Pattern } \\
\text { Consumption in } \\
\text { Ramadan }\end{array}\end{array}$ & 0.446 & 0.470 & 0.063 & 7.128 & 0.000 \\
\hline
\end{tabular}

(Source: Processed form questionnaire data).

Based on the data in the table above, it can be seen that the latent variable that indirectly has a relationship or influence is found in the latent variable of religiosity factor on consumption patterns of the people of Jambi city in the month of Ramadan. The results of Indirect Effects have an influence on the endogenous variables in the medium category of 0.446 with $\mathrm{T}$ statistics of $7.128>1.96$ and a significance level of $0.0000<0.05$.

Meanwhile, the variable that mediates the latent exogenous variable of the religiosity factor with the endogenous variable of consumption patterns of the Jambi city community in the month of Ramadan is the latent variable of social factors. The following diagram will describe the symbol of the relationship and indirect influence between the latent variable of factor religiosity with consumption patterns of the people of Jambi city in Ramadan and social factors as the latent variable as an intermediary variable.

\section{Faktor Sosial -> Pola Konsumsi pada Bulan} Ramadhan

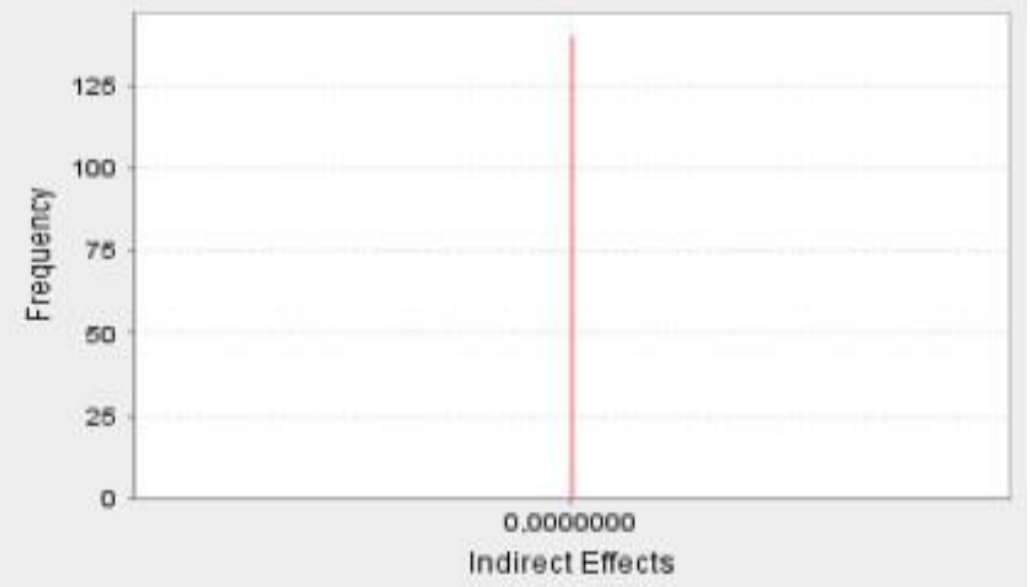

(Source: processed from questionnaire data).

Fig. 2. Diagram Indirect Effects. 
From the calculation results above, the latent variable of religiosity indirectly affects the consumption pattern of the Jambi city community in the month of Ramadan $44.6 \%$. This number is positive, so it can be said that latent spiritual variables have an influence on consumption patterns through latent social variables. So it can be said that the stronger the practice of religiosity values carried out by the people of the city of Jambi will increase the social activities of the people of the city of Jambi in everyday life. The increasing social activities of the people of Jambi city will affect consumption patterns, especially in the month of Ramadan. Consumption activities that are influenced by social factors in the Jambi city community are in the form of fulfilling consumption needs for breaking the fast according to requests from several family members, such as the recommendation to break the fast with sweet foods and some special foods that are the favorites of family members. Buying some clothes, new sandals, preparing for Eid consumption and homecoming accommodation are forms of consumption patterns to celebrate Eid. Wearing new clothes, respecting guests who come to stay in touch by providing various kinds of food during Eid, and traveling back and forth to maintain a friendship with families who live in the village during Eid is part of the influence of religiosity on consumption patterns through social interaction and developing into a culture.

The practice of religious teachings will increase awareness of the meaning of social relations as described in the following verse of the Qur'an.

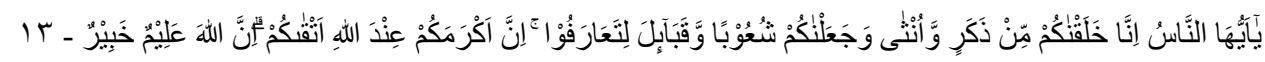

Meaning:

O mankind, indeed We created you from a male and a female and made you into nations and tribes so that you may know one another. Verily, the most honorable of you in the sight of Allah is the one who is most pious among you. Verily Allah is All-Knowing, All-Knowing. (AlHujurat, 49:13).

Based on the understanding of the verse above, the role of social relations is largely determined by the level of piety in which social relations will become a relationship harmonious which will be seen from the commitment in carrying out all the rules in religiosity. so that it can be an inspiration for individuals in determining every decision to be taken. Individual inspiration produces a concern, motivation, and commitment to doctrine the family as a form of responsibility. This condition is confirmed in the following paragraph.

Meaning:

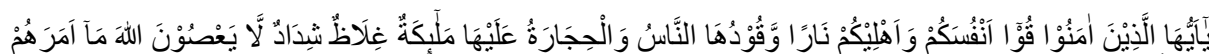

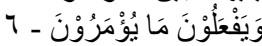

O you who believe, protect yourselves and your families from a hellfire whose fuel is people and stones; His guardians are angels who are harsh, harsh, and do not disobey Allah for what He commands them and always do what they are commanded. ${ }^{1}$ (At-Tahrim, 66:6) [14].

Social influence in the formation of consumption patterns can be seen from the explanation of the following verse.

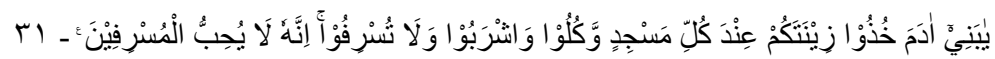

Meaning:

\footnotetext{
${ }^{1}$ Depag RI, Al-Quran Translation, p. 947
} 
O son of Adam, wear your beautiful clothes in every (enter) the mosque ${ }^{[534]}$, eat and drink, and do not be extravagant ${ }^{[535]}$. Verily, Allah does not like those who are extravagant. ${ }^{2}$ (Al-Araf, $7: 31$ ) [14].

Wearing the most beautiful clothes is part of a consumption pattern that is indirectly influenced by social interaction in the form of cultural development by creating appropriate and beautiful clothes to be used in congregational prayers in the mosque. Consumption activities carried out are a form of religiosity motivation by providing freedom of social creativity so that it can generate an idea and develop creativity in consumption patterns.

\section{Conclusion}

The indirect effect of consumption patterns of the Jambi city community in the month of Ramadan shows that the higher the level of religiosity of the community will affect social actions related to consumption such as reference groups who will recommend purchasing all necessities for needs during Ramadan and Eid, making iftar activities together or charity events on Ramadhan month. A culture that is a formative variable will give birth to a tradition such as going home and distributing THR. This influence will shape the consumption pattern of the people of Jambi city and will increase household consumption spending during the month of Ramadan and after.

\section{References}

[1] A. Uyar, C. Kuzey, A. H. Güngörmüs, and R. Alas, "Influence of theory, seniority, and religiosity on the ethical awareness of accountants," Soc. Responsib. J., vol. 11, no. 3, pp. 590-604, 2015, doi: 10.1108/SRJ-06-2014-0073.

[2] N. Muhamad and D. Mizerski, "The constructs mediating religions' influence on buyers and consumers,” J. Islam. Mark., vol. 1, no. 2, pp. 124-135, 2010, doi: 10.1108/17590831011055860.

[3] Jalaluddin, Psychology of Religion. Jakarta: RajaGrafindo Persada, 2016.

[4] R. Madjid, Modern Islam and Indonesianness. Bandung: Mizan Pustaka, 1997.

[5] Z. Darajat, Religious Psychology. Jakarta: Bulan Bintang, 1991.

[6] Barrnet, "Ethical Ideology, and intentions to Report A Peer's Wrongdoing," J. Bus. Ethics, vol. 15, no. 11 , pp. 1161-1175, 2016.

[7] "Sosial." https://kbbi.web.id/sosial .

[8] A. S. Susanto, Introduction to Sociolagi and Social Change. Jakarta: Bina Cipta, 1985.

[9] M. Abdullah and N. S. Sapiei, "Do religiosity, gender and educational background influence zakat compliance? The case of Malaysia," Int. J. Soc. Econ., vol. 45, no. 8, pp. 1250-1264, 2018, doi: 10.1108/IJSE-03-2017-0091.

[10] A. Rahmawati, Islamic Microeconomics. Holy: Nora Media Enterprise, 2011.

[11] S. Nawab haidar Naqfi, Ethics and Economics, an Islamic Synthesis. Bandung: Mizan, 1985.

[12] M. Khaf, Islamic Economics (Analytical Study of the Functions of an Islamic Economic System). Yogyakarta: Pustaka Pelajar, 1995.

[13] A. Manna, Theory and Practice of Islamic Economics. Yogyakarta: PT Dana Bakti Waqf, 1993.

[14] M. of R. of the R. of Indonesia, Al-Quran Translation,Dister, Psychology of Religion. Yogyakarta: Knisius, 1989.

\footnotetext{
${ }^{2}$ Depag RI, Al-Quran Translation, p. 225
} 